\title{
BEDAH KARYA POSTER DESAIN UNTUK DIFABEL MENGGUNAKAN TEORI SEMIOTIKA
}

\author{
Sari Wulandari \\ Jurusan Desain Komunikasi Visual, School of Design, BINUS University \\ Jln. K.H. Syahdan No. 9, Palmerah, Jakarta Barat 11480 \\ swulandari@binus.edu
}

\begin{abstract}
Year of 2011 was a special year for the people of Indonesia with ASEAN ParaGames held in Solo on December $12^{\text {th }}$ to December $20^{\text {th }}$. Solo held ASEAN Paralympic Games in 2011 in the month of December. These special moments were used by Aikon Media, ADGI (Asosisasi Graphic Designers Indonesia), and DKV BINUS to organize a poster exhibition with works by students and lecturers of DKV BINUS University, DKV UNS Solo and Solo ADGI chapter called "Design for the disabled". The messages on the poster were addressed to the public, particularly people with disabilities who are called by "the difable" with the objective of improving people's appreciation of the difable. So that, the resulting confidence higher to those who can then deliver them to better performance. The study was conducted to see the visual signs contained in the poster work of students $D K V$ BINUS semester 3 done by using the theory of semiotics. It can be concluded that the communication with empathy for the disabled is the main one, and then conveyed through visual signs that have meaning and can be accepted and understood by the audience.
\end{abstract}

Keywords: poster design, difable, semiotic

\begin{abstract}
ABSTRAK
Tahun 2011 merupakan tahun yang istimewa bagi bangsa Indonesia dengan diselenggarakannya ASEAN Para Games di kota Solo pada tanggal 12-20 Desember 2011. Kota Solo akan mengadakan ASEAN Paralympic Games 2011 di bulan Desember ini. Momen istimewa ini digunakan oleh Aikon Media, ADGI (Asosisasi Desainer Grafis Indonesia) dan DKV BINUS untuk menyelenggarakan kegiatan pameran poster bersama karya para mahasiswa dan dosen DKV BINUS University, DKV UNS Solo dan ADGI chapter Solobernama "Desain untuk Difabel". Pesan pada poster ditujukan kepada masyarakat luas, terutama para penyandang cacat yang disebut dengan difabel dengan objektif yaitu meningkatkan apresiasi masyarakat terhadap para difabel sehingga timbul rasa percaya diri yang lebih tinggi pada diri mereka yang selanjutnya dapat mengantarkan mereka kepada prestasi yang lebih baik lagi. Penelitian ini dilakukan untuk melihat tanda visual yang tertuang pada poster karya mahasiswa DKV BINUS semester tiga yang dibedah dengan menggunakan teori Semiotika. Dapat disimpulkan bahwa komunikasi dengan empati kepada para difabel adalah yang utama yang kemudian disampaikan melalui tanda visual yang memiliki makna dan dapat diterima serta dipahami oleh pemirsa.
\end{abstract}

Kata kunci: desain poster, difabel, semiotika 


\section{PENDAHULUAN}

Tahun 2011 merupakan tahun yang istimewa bagi bangsa Indonesia di mana kita mendapat kehormatan untuk menyelenggarakan SEA Games ke 26. Seperti yang sudah sering dilakukan, setiap penyelenggaraan SEA Games selalu diikuti dengan penyelenggaraan ASEAN ParaGames. Demikian juga pada tahun ini, ASEAN ParaGames diselenggarakan di kota Solo beberapa hari setelah SEA Games usai, tepatnya pada tanggal 12-20 Desember 2011. Kota Solo mengadakan ASEAN Paralympic Games 2011 di Bulan Desember 2011. Dalam APG 2011 akan dipertandingan 11 cabang olahraga seperti atletik, akuatik, bulutangkis, catur, voli duduk, renang, tennis, angkat berat dan lain-lain. Lebih dari 1.000 atlet dan official akan berpartisipasi dalam perhelatan empat tahunan ini.

Momen yang istimewa ini mendatangkan inspirasi bagi Aikon Media, ADGI (Asosisasi Desainer Grafis Indonesia), dan DKV BINUS untuk menyelenggarakan kegiatan yang dapat mendorong isu aksesibilitas difabel ke tengah masyarakat. Kegiatan yang diselenggarakan masih dalam lingkup desain grafis berupa pameran poster bersama karya para mahasiswa dan dosen DKV BINUS University, DKV UNS Solo dan ADGI chapter Solo. Difabel adalah sebutan lain untuk penyandang cacat, yang merupakan singkatan dari 'different ability' menggantikan kata 'disable' atau 'disability' karena berkonotasi 557iteratu. Selain itu penyebutan dengan kata 'difabel' dimaksudkan untuk lebih menghargai situasi dan kondisi yang ada pada penyandang cacat bahwa mereka bukannya tidak bisa namun punya kemampuan yang berbeda.Dengan adanya momen ini maka dibuatlah kegiatan yang merupakan program DoGoodIndonesia \#2 yaitu "Desain untuk Difabel” dengan tujuan pertama, mendorong perhatian masyarakat pada ASEAN Paralympic Games Solo 2011, melalui pemberdayaan 557itera dengan different ability (difabel). Kedua, mendukung perhatian pemerintah Kota Solo kepada 557itera difabel.

Sebagai puncak kegiatan maka pada tanggal 12-14 Desember 2011 tiga lembaga ini (Aikon, ADGI, dan DKV BINUS) dengan bekerjasama dengan Fakultas Desain Komunikasi Visual Universitas Negeri Surakarta dan Asosiasi Desain Grafis Solo Chapter menyelenggarakan pameran Poster dan Audio Visual bertema difabilitas, karya mahasiswa dan dosen di Gedung Kesenian Sriwedari, Solo. Program ini sekaligus untuk mendorong kontribusi profesi desainer grafis dan kiprah mahasiswa komunikasi visual bergiat dalam pemberdayaan 557itera, budaya, dan lingkungan dalam menjalankan praktek profesionalnya. Pameran ini menampilkan 20 karya dari mahasiswa dan dosen DKV BINUS, 15 karya mahasiswa dan dosen UNS Solo dan 4 karya desainer yang tergabung dalam ADGI chapter Solo. Dalam komunikasinya diarahkan bahwa poster-poster ini akan mengusung semangat dan 557iteratu bagi para difabel dan masyarakat umum.

Sebelum call for poster diluncurkan, diadakan workshop dengan mengundang Bapak Sapto Nugroho dari Yayasan Talenta, Solo. Bapak Sapto ini adalah seorang difabel. Beliau adalah pendiri dan 557iterat Yayasan Talenta yang bergerak di bidang pemberdayaan terhadap para difabel sehingga mereka dapat memperoleh kesempatan kerja dan berkehidupan yang lebih baik dari sebelumnya. Beberapa diskusi sederhana dan sebuah sarasehan di DKV Binus dilakukan untuk memberikan pengetahuan yang lebih baik dan mendorong munculnya semangat keterlibatan desainer grafis di dunia difabel.Diskusi di dunia maya melalui jaringan media 557itera pun dilakukan. Semangat berkontribusi untuk isu difabilitas kemudian berkembang menjadi persiapan perayaan Hari Difabel Internasional yang diperingati setiap tanggal 3 Desember yang dikaitkan dengan penyelenggaraan ParaGames ASEAN ke-6 di Solo.

Workshop ini merupakan bagian dari metode observasi yang kemudian diperoleh insight mengenai situasi dan kondisi difabilitas di Indonesia saat ini, terlihat secara kasat mata dengan fasilitas 557itera bagi para difabel masih sangat kurang diperhatikan (kampus BINUS sendiri masih belum menyediakan fasilitas yang memadai untuk difabel). Namun di samping itu, para difabel pun memiliki 
pergulatan batin dalam menghadapi kondisi pada dirinya. Dari observasi awal, diperoleh beberapa poin permasalahan yang ada di sekitar isu difabel adalah: pertama, kemampuan 558itera difabel masih tidak diakui, atau dianggap tidak setara dengan 558itera non-difabel, sehingga masih banyak dirasakan adanya diskriminasi terhadap difabel di lapangan kerja dan pendidikan. Hal inilah yang perlu untuk disosialisasikan di masyarakat bahwa mereka para difabel memiliki kemampuan yang sama dengan non-difabel namun dengan cara yang berbeda. Kedua, melibatkan 558itera non-difabel dalam kegiatan kemanusiaan yang masih minim perhatian, serta menjadi ruang pembelajaran bagi banyak pihak, khususnya para pihak di bidang komunikasi visual.

Pada bulan September 2011 adalah masa para atlet difabel Paralimpik berlatih.Untuk lebih memperkaya wawasan dan pengetahuan mengenai berkomunikasi dengan para difabel maka dilakukanlah kunjungan ke lokasi latihan untuk mempertajam insight melalui observasi dengan melihat dari dekat bagaimana para atlet difabel renang berlatih di Stadion Renang Tirtomoyo, Solo. Pemandangan yang sungguh membuat perasaan tidak menentu.Ada rasa haru, iba, semangat, bangga yang saling bercampur aduk menjadi satu. Para atlet renang difabel berlatih tanpa henti di bawah instruksi para pelatih nasional yang menerapkan disiplin sangat ketat, tanpa membedakan apakah atlet yang dibinanya adalah seorang difabel atau non-difabel. Mayoritas atlet adalah tunadaksa, tunanetra dan tunagrahita. Semangat yang dimiliki para atlet ini sungguh luar biasa.

Untuk lebih memperkaya pengetahuan dan pendalaman pemahaman akan difabilitas, maka dilakukan studi literatur dengan mencari data dan informasi mengenai difabilitas baik melalui pustaka maupun internet berupa teks, foto atau video. Literatur ini juga bermanfaat untuk disebarluaskan kepada para mahasiswa dan dosen ketika mereka berpartisipasi dalam membuat karya poster untuk kegiatan ini. Dengan demikian, akan semakin banyak masyarakat yang peduli mengenai difabilitas, lebih menghargai dan memerhatikan kebutuhan para difabel dan meningkatkan eksistensinya di masyarakat.

Berikut ini adalah beberapa karya poster pameran Desain untuk Difabel dari DKV BINUS yang ditampilkan di Gedung Kesenian Surakarta, Solo pada tanggal 12-16 Desember 2011 dalam rangka hari Difabel Internasional dan menyambut ASEAN ParaGames ke- 6 di Solo. Poster-poster ini dipilih karena banyak menarik perhatian masyarakat pada pameran ini selain secara keilmuan Desain Komunikasi Visual memiliki elemen visual yang sarat dengan tanda.
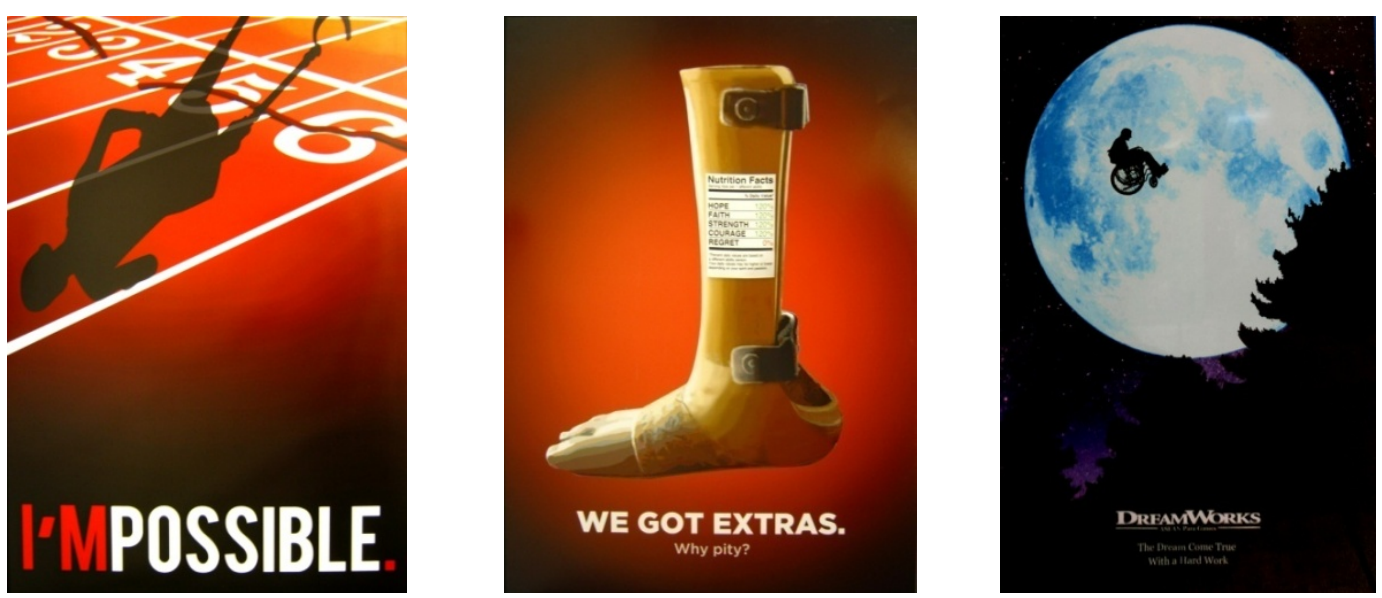

Gambar 1 Poster untuk Difabel dari DKV BINUS 


\section{METODE PENELITAN}

Metode yang akan digunakan dalam penelitian ini adalah Metodologi Observasi dan Partisipatif dengan melakukan survei dan pengamatan dengan membuat workshop serta mengunjungi dan melihat para atlet difabel berlatih. Selain itu dilakukan Studi Kepustakaan dengan melakukan riset pustaka baik cetak maupun online dengan topik-topik yang berhubungan dengan difabilitas, serta Wawancara Narasumber Terkait yaitu wawancara dengan para penyandang cacat untuk mengetahui insight dari yang mereka pikirkan dan rasakan mengingat mereka yang akan menjadi subjek sekaligus objek dari kegiatan pameran ini.

\section{HASIL DAN PEMBAHASAN}

Melalui metode observasi dan partisipatif telah dilakukan pengamatan atas para difabel, baik yang berada di Jakarta maupun di kota Solo. Diawali dengan menggelar sebuah workshop dengan mengundang Bapak Sapto Nugroho dari Yayasan Talenta, Solo yang seorang difabel. Beberapa diskusi sederhana dan sebuah sarasehan di DKV Binus dilakukan untuk memberikan pengetahuan yang lebih baik mengenai dunia difabilitas. Untuk lebih memperdalam pengetahuan dan pemahaman, dilakukan kunjungan ke lokasi latihan dengan melihat dari dekat bagaimana para atlet difabel renang berlatih di Stadion Renang Tirtomoyo, Solo. Selain itu juga dilakukan wawancara dengan beberapa difabel serta para pelatih atlet renang difabel.

Dari observasi dan wawancara yang dilakukan, dapat disimpulkan bahwa sering kali terjadi adanya masalah komunikasi timbal balik antara masyarakat dan diri difabel, yang tercermin pada sikap dan perlakuan terhadap difabel dan difabilitas. Untuk itu, masyarakat perlu memahami kondisi difabel danmenerima eksistensi mereka. Sebaliknya, para difabel sendiri perlu untuk menerima kondisi dirinya, dengan menganalisis diri untuk menemukan jati dirinya dan potensi yang ada pada dirinya, diberi kesempatan untuk berinteraksi secara sosial sehingga tercipta aktualisasi diri di masyarakat yang akhirnya membentuk eksistensi pribadi. Melalui Studi Kepustakaan, ditinjau dari sudut disiplin ilmu Desain Komunikasi Visual khususnya seputar ilmu semiotika yang merupakan ilmu mempelajari bahasa tanda. Dalam perkembangannya, Semiotika adalah ilmu yang mempelajari tentang tanda (sign), tentang berfungsinya sebuah tanda dan terciptanya sebuah makna.Tanda-tanda tersebut menyampaikan suatu informasi sehingga bersifat komunikatif. Cabang ilmu ini semula berkembang dalam bidang bahasa, kemudian berkembang pula dalam bidang seni rupa dan Desain Komunikasi Visual, menjadi sebuah metodologi yang mengeksplorasi struktur untuk membantu menyibak makna yang terkandung dalam sebuah karya desain, bahkan dalam sebuah aktivitas budaya.

Sekitar tahun 1960-an desainer mulai menyadari peran ilmu semiotika sebagai sebuah cara untuk memahami sebuah karya desain dan sebaliknya untuk membantu agar sebuah karya desain dapat berkomunikasi secara tepat kepada konsumennya. Tidaklah mengherankan jika cabang ilmu ini dapat berkembang pesat mengingat salah satu kebutuhan manusia adalah berkomunikasi. Manusia berkomunikasi melalui tanda yang direpresentasikan dalam bentuk gerakan, isyarat, suara, tulisan, gambar, dan lain-lain yang dengan bentuk-bentuk ini sangat dekat dengan karya-karya yang dihasilkan oleh seorang desainer komunikasi visual. Oleh karena itu, sangat tepat apabila Teori Semiotika digunakan sebagai alat bantu bedah sebuah karya Desain Komunikasi Visual karena dalam proses penciptaannya seorang desainer akan mempertimbangkan pemilihan elemen-elemen desain serta prinsip desain yang sesuai dalam mengatur elemen-elemen desain sehingga dapat menimbulkan makna yang tepat bagi target audiensnya. 
Dalam keilmuan DKV dikenal dua orang tokoh semiotika, yaitu Ferdinand de Saussure (18571913) dan Charles Sander Peirce (1839-1914). Saussure yang memiliki latar belakang lingusitik menyebut ilmu ini Semiology. Sedangkan Pierce yang berlatar belakang filsafat menyebutnya Semiotics.

Semiology menurut Saussure, didasarkan pada anggapan bahwa selama perbuatan dan tingkah laku manusia membawa makna atau selama berfungsi sebagai tanda. Hal ini berarti di belakangnya terdapat sistem pembedaan dan konvensi yang memungkinkan terbentuknya makna itu, ada tanda maka di sana ada sistem. Artinya, sebuah tanda mempunyai 2 aspek yang ditangkap oleh manusia. Yang pertama adalah yang disebut dengan Signifier, yaitu penanda atau sesuatu yang terlihat dan mempunyai wujud seperti bunyi, huruf, kata, gambar, warna, objek, dan lain-lain. Aspek kedua adalah yang disebut dengan Signified, yaitu petanda atau konsep atau makna. Kedua aspek ini sifatnya arbiter (terpisah, tidak ada hubungan).

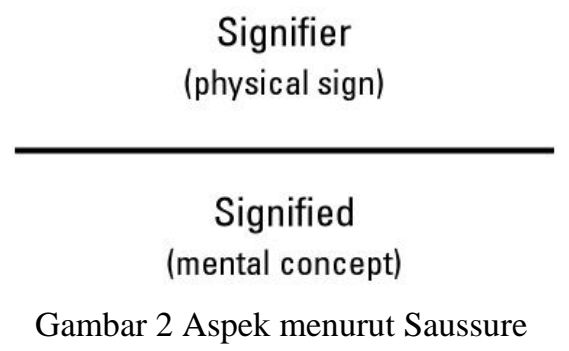

Sedangkan semiotika menurut Peirce, penalaran manusia senantiasa dilakukan lewat tanda.Tanda baru dapat berfungsi apabila diintepretasikan di dalam benak penerima tanda, melalui pemahaman makna yang muncul dalam diri penerima tanda. Dengan kata lain, sebuah visual dapat berfungsi sebagai tanda apabila memiliki 3 komponen yang dikenal dengan Triadic Semiotic, yaitu memiliki Representamen (sesuatu yang direpresentasikan), ada Objek (kerangka acuan atau makna) dan ada Interpretan (memungkinkan adanya interpretasi). Untuk lebih jelasnya dapat dilihat pada semiotika Peirce berikut.

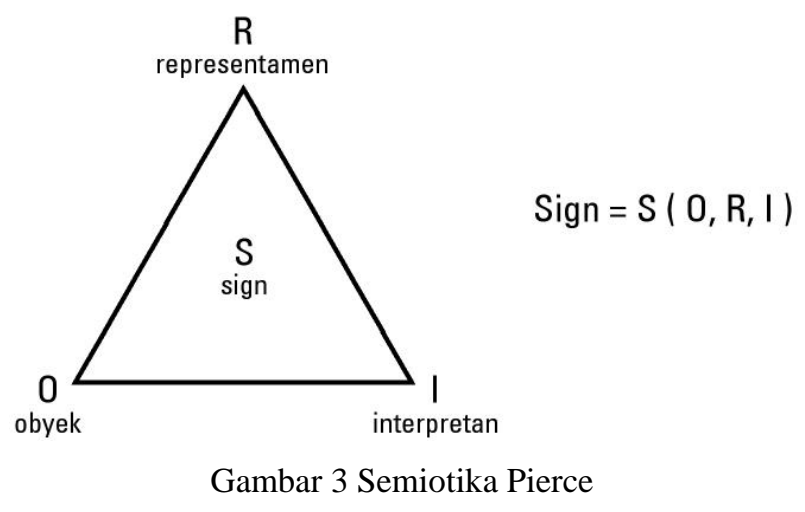

Dengan demikian, sebuah tanda dapat diteliti, dipelajari dan berfungsi sebagai pintu masuk untuk mengetahui terciptanya sebuah ekspresi, representasi dan selanjutnya dapat menimbulkan pengetahuan baru, seperti yang tergambar berikut ini. 


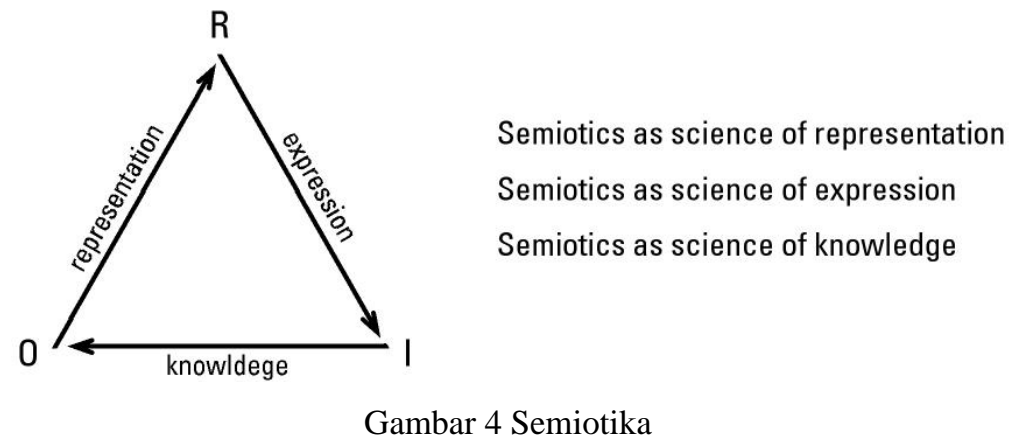

Ilmu desain berkembang lintas disiplin ilmu secara luas dan berproses secara heterogen. Oleh karenanya tidak tertutup kemungkinan tanda dapat memiliki berbagai macam interpretasi.Tanda (Representamen) sebagai representasi dari sebuah Objek dapat diklasifikasikan menjadi 3 jenis tanda.Yang pertama adalah ikon, yaitu tanda di mana antara tanda dengan acuannya terdapat hubungan kemiripan (metafora). Pada Ikon, Representamen merupakan representasi dari Objek dan Interpretan mengacu kepada keduanya. Contohnya, potret wajah merupakan representasi dari sebuah wajah dan interpretan membuat hubungan antara keduanya.Yang kedua adalah indeks yaitu apabila ada hubungan kedekatan eksistensi antara tanda dengan acuannya. Pada indeks, interpretan cukup mengacu pada representamen saja karena representamen merupakan representasi dari objek. Contohnya, dengan melihat adanya asap maka interpretan dapat mengetahui adanya api.Yang terakhir adalah simbol, yaitu apabila tanda diakui keberadaannya berdasarkan hukum konvensi. Pada simbol, interpretan memiliki hubungan dengan objek dan hubungan dengan representamen namun objek dan representamen tidak berhubungan secara langsung. Contohnya, interpretan menganggap benda untuk menyimpan uang adalah dompet dan interpretan menulis benda tersebut sebagai d-o-m-p-e-t, namun antara benda dan d-o-m-p-e-t tidak ada hubungan secara langsung. Penjelasan mengenai hubungan representamen-objek-interpretan pada pemaknaan ikon, indeks, dan simbol dapat dilihat melalui diagram Peirce (Gambar 5).

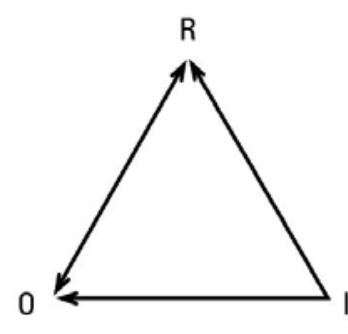

Iconic

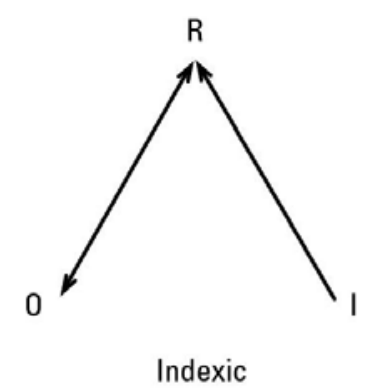

Gambar 5 Diagram Peirce

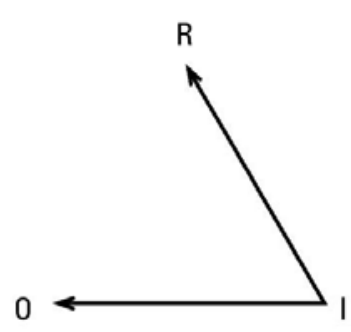

Symbolic

Tokoh semiotika lainnya, Charles Morris (1901-1979) mengikuti Peirce dalam menggunakan istilah semiotic dengan mengembangkan pemakaian tanda dan pemaknaannya serta menghubungkan tanda tersebut dengan perilaku. Ia menambahkan bahwa terjadi tingkatan semiotika, bahwa tanda berproses secara bertahap yaitu: (1) sintaks, jika terdapat hubungan antara satu tanda dengan tanda lain, tanda menjadi Representamen. Sintaks tidak hanya dibatasi mempelajari hubungan antara tanda di dalam sistem tanda yang sama, melainkan juga mempelajari tanda dalam sistem lain yang menunjukkan kerjasama. Misalnya dalam film, antara gambar dan kata-kata, pada dasarnya berasal dari sistem tanda yang berbeda, namun keduanya bekerjasama. Dalam linguistik, sintaks merupakan ilmu yang mempelajari prinsip dan aturan dalam membangun kalimat. Dalam disiplin keilmuan DKV, sintaks mempelajari prinsip desain dan hubungan antarelemen grafis, dalam perancangan sebuah desain; (2) semantik, yaitu hubungan antara tanda (Representamen) dengan Objek, sehingga 
menimbulkan makna. Semantik merupakan ilmu yang mempelajari pemaknaan tanda yang digunakan oleh masyarakat tertentu dalam situasi dan konteks tertentu. Mengingat pemaknaan ini terkait dengan situasi dan konteks tertentu, maka dalam Semantik dikenal adanya Semantik Denotatif, yaitu makna yang tersirat dan Semantik Konotatif, yaitu makna yang tersurat; (3) pragmatik, yaitu pemaknaan (hasil semantik representamen kepada objek) yang dihubungkan dengan penggunanya (interpretan) sehingga konteks penggunaan tanda dapat teridentifikasi. Makna sebuah representamen dapat berubah, tergantung pada interpretan. Perhatikan gambar berikut.

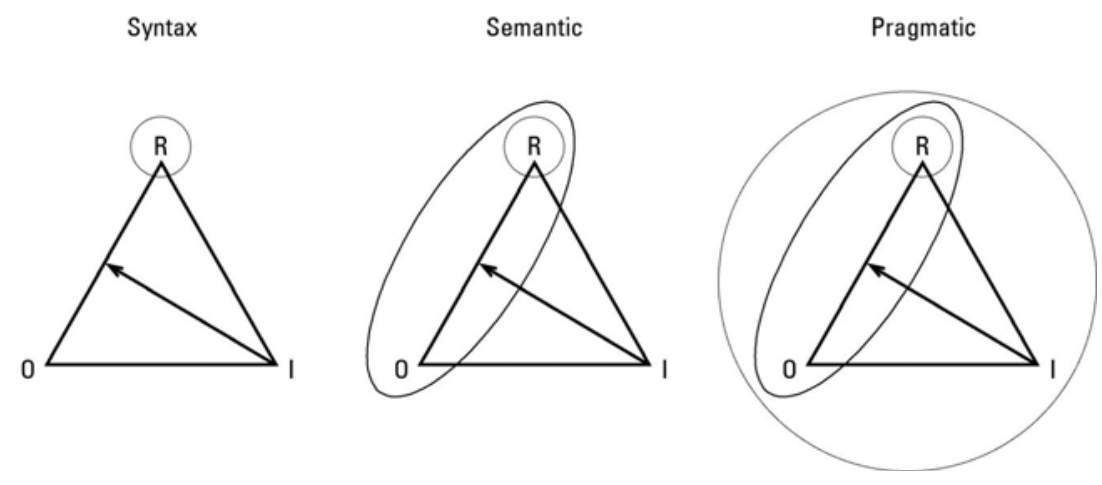

Gambar 6 Diagram syntax, semantic dan pragmatic

Agar tanda dapat berfungsi maka representamen diterjemahkan ke dalam Ground, yaitu sistem tanda yang ada dalam suatu masyarakat, biasanya berbentuk Kode. Salah satu contoh Kode adalah bahasa. Pada praktiknya, sebuah pesan dikirim oleh pengirim pesan melalui seperangkat kode yaitu susunan huruf yang membentuk kata (yang dipahami melalui sebuah konvensi) oleh penerima pesan. Seseorang dapat melakukan komunikasi karena adanya ground yang berbentuk Kode. Ketika hendak mengirim pesan ia melakukan encoding (menterjemahkan makna ke dalam ground) dan ketika menerima pesan ia melakukan decoding (mengintepretasikan ground untuk menangkap makna).

Proses komunikasi ini dapat dijelaskan melalui Model Komunikasi dari Wilbur Schramm (1954) yang memopulerkan Schramm's Interactive Model. Dijelaskan dalam bukunya The Process and Effects of Communication, bahwa proses decoding dan encoding adalah aktivitas yang terjadi secara terus menerus yang dilakukan oleh pengirim dan penerima pesan sehingga terjadi komunikasi dua arah. Ia menegaskan bahwa hal ini dimungkinkan dengan adanya peran interpreter (secara abstrak) dalam memecahkan masalah pemaknaan. Untuk lebih jelasnya dapat dilihat pada diagram Komunikasi Model Wilbur Schramm di bawah ini.

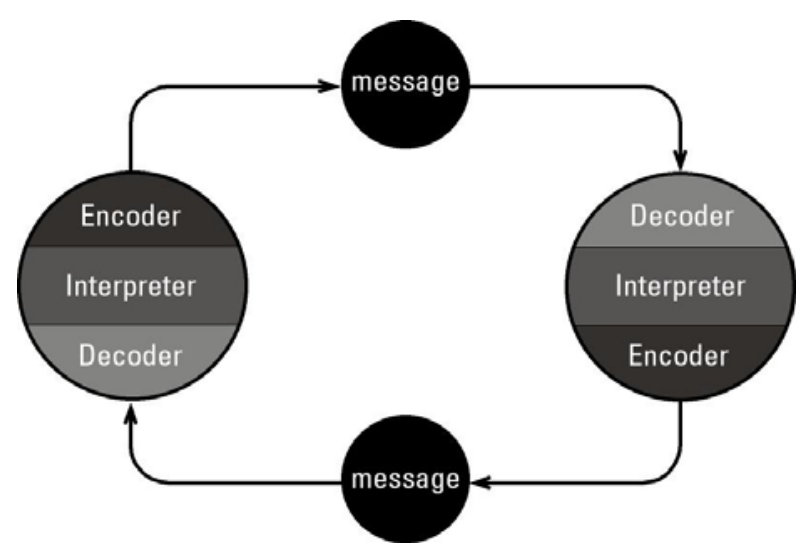

Gambar 7 Diagram Komunikasi Model Wilbur Schramm 
Roland Barthes mengembangkan metode semiotika untuk desainer melalui analisisnya terhadap kompleksitas tanda dengan melihat pengalaman konsumen terhadap desain. Bukunya berjudul Mythologies (1957) adalah yang pertama mengembangkan sebuah analisis semiologis dari desain, di mana ia mengenalkan 3 tingkatan dalam pemaknaan sebuah tanda. Tingkat pertama adalah pemaknaan secara denotatif, yaitu makna tertangkap secara langsung. Misalnya, figur pada gambar mobil balap berarti 'ini adalah mobil sport'. Tingkat kedua adalah pemaknaan secara konotatif, yaitu makna yang tersirat secara tidak langsung, dimana figur gambar mobil balap dimaknakan sebagai 'kehidupan moderen yang serba cepat'. Tingkatan yang ketiga adalah mitologi. Pengertian mitologi di sini adalah mitos-mitos yang hidup di era modern baik dalam lingkup kebendaan, peran maupun karakter. Mitologi terbentuk melalui pemikiran mitos yang dipadukan dengan pemikiran rasional.Gambar mobil balap disini secara mitologi dapat menyimbolkan 'kekuatan, kekuasaan, kebebasan' namun tergantung pada profil masyakat yang melihat (gender, usia, kelas). Dengan mempelajari mitos dapat diketahui sebuah kelompok masyarakat menjawab permasalahan yang ada di dalam kehidupan mereka. Selanjutnya dapat diketahui bagaimana latar belakang sekelompok manusia dalam mengembangkan tatanan kehidupan, prinsip hidup serta nilai-nilai yang dapat menyatukan mereka dalam sebuah kelompok sosial.

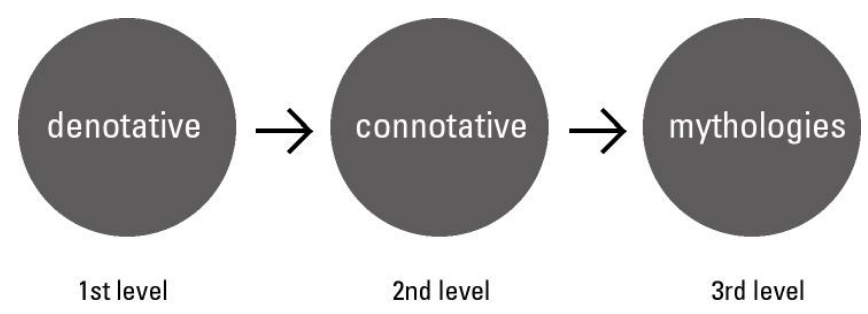

Gambar 8 Tiga Tingkatan Metode Semiotika Barthes

Berdasarkan proses desain yang dijelaskan oleh David Smith dalam Design for Content Management (2010), form, content, dan context berkaitan erat dengan proses semiosis dari Morris yaitu sintaks merupakan dengan form (tampilan visual/representamen), semantik merupakan content (pesan yang akan disampaikan/objek), dan pragmatik merupakancontext (mempertimbangkan kebutuhan, profil penerima pesan/interpretan). Untuk lebih jelasnya dapat dilihat pada diagram di bawah ini.

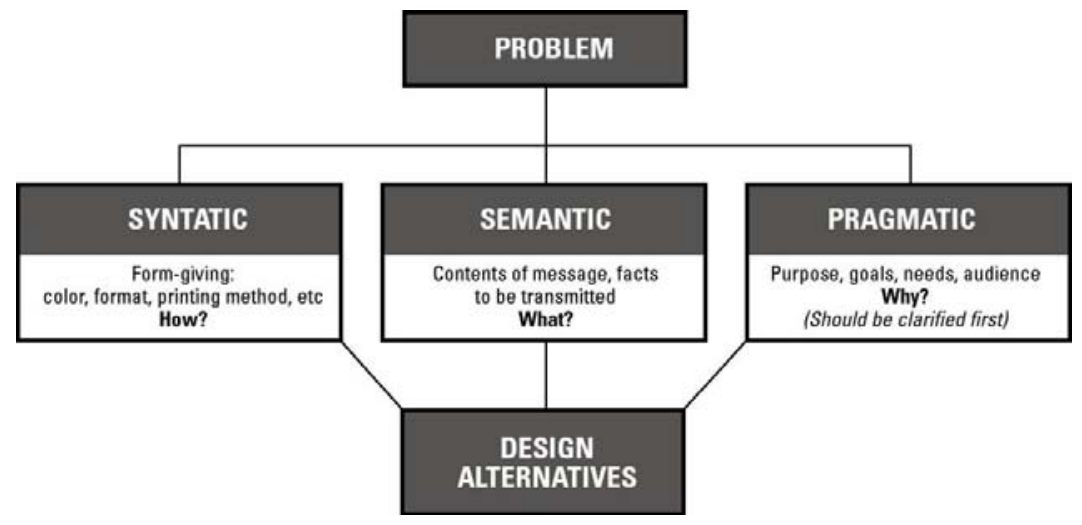

Gambar 9 Proses Desain Smith

Dalam membahas karya-karya poster dalam penelitian ini menggunakan teori Semiotika dari Charles Morris dan Roland Barthes, serta Proses Desain dari David Smith. Berikut ini adalah beberapa karya poster pameran Desain untuk Difabel dari DKV BINUS yang ditampilkan di Gedung Kesenian 
Surakarta, Solo pada tanggal 12-16 Desember 2011 dalam rangka hari Difabel Internasional dan menyambut ASEAN ParaGames ke- 6 di Solo. Poster-poster ini dipilih karena banyak menarik perhatian masyarakat pada pameran ini selain secara keilmuan Desain Komunikasi Visual memiliki elemen-elemen visual yang sarat dengan tanda.

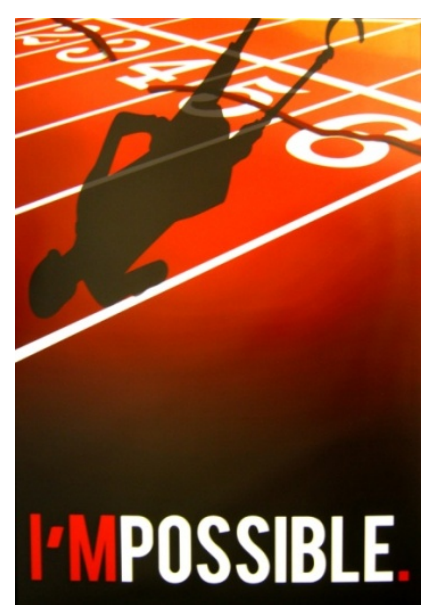

Gambar 10 Poster berjudul I'mPossible karya Steffi

Poster berjudul I'mPossible karya Steffi (Gambar 10), sebagai representamen ditampilkan sosok figur bayangan dari seorang difabel dengan pita yang terlihat seolah baru saja putus.Selain itu diperlihatkan adanya angka-angka dengan garis-garis putih di atas bidang berwarna jingga tua. Beberapa representamen di sini bekerjasama dan membentuk makna denotatif bahwa lokasi adalah lintasan lapangan atletik dan sosok figur manusia adalah seorang atlet berada di garis finish. Dalam konteks olahraga representamen ini dengan segera menimbulkan interpretasi bahwa seorang atlet difabel baru saja memenangkan lomba.Yang juga menarik di sini meskipun eksekusi dilakukan dengan ilustrasi, namun cara mengggambarkannya sangat fotografis dengan melakukan pemotongan gambar (cropping) serta mengadakan ruang kosong untuk kemudian ditempatkan headline pada ruang tersebut dengan kata "I'm Possible" yang memperkuat pesan pada gambar bahwa para difabel mampu untuk mencapai prestasi.Kata I'mPossible sendiri ditulis dengan cara mendekatkan kedua kata namun dibedakan pada warna sehingga terlihat bahwa seolah-olah kata "Impossible" berubah menjadi "I'm Possible". Dapat disimpulkan poster ini menyampaikan pesan bahwa walaupun kondisi fisik seorang difabel berbeda (berkekurangan) jika dibandingkan dengan mereka yang non-difabel, yang pada umumnya dianggap tidak mampu bahkan dianggap tidak mungkin meraih prestasi, namun ternyata mereka memiliki kemampuan yang luar biasa, bahkan dapat melebihi mereka yang non-difabel.

Poster berjudul We Got Extras karya Angel Stephanie (Gambar 11), sebagai representamen ditampilkan sebuah kaki palsu yang terbuat dari kayu yang kokoh dan dilengkapi dengan material besi. Selain itu diperlihatkan adanya label yang menginformasikan komposisi kandungan nutrisi yang umumnya tercantum pada kemasan makanan atau minuman. Pada label tercantum komposisi bahwa kandungan nutrisi banyak mengandung 'harapan, kekuatan, keberanian' dan tidak ada 'penyesalan'. Beberapa representamen di sini bekerjasama dan membentuk makna denotatif bahwa kaki palsu memiliki banyak kelebihan. Dalam konteks difabilitas representamen ini menimbulkan interpretasi bahwa dalam kondisi kecacatan, seseorang perlu dibantu dengan menggunakan kaki palsu. Namun, keadaan ini justru memberikan tingkat kekuatan dan harapan lebih tinggi bila dibandingkan pada mereka yang non-difabel. Pesan ini diperkuat dengan adanya headline dan sub-headline "We Got Extras - Why Pity?". Dapat disimpulkan poster ini menyampaikan pesan bahwa seorang difabel tidak perlu merasa berkecil hati karena meskipun mereka berbeda, kondisi ini memungkinkan mereka untuk memiliki kekuatan dan keberanian lebih besar sehingga mampu untuk berkarya lebih baik. 


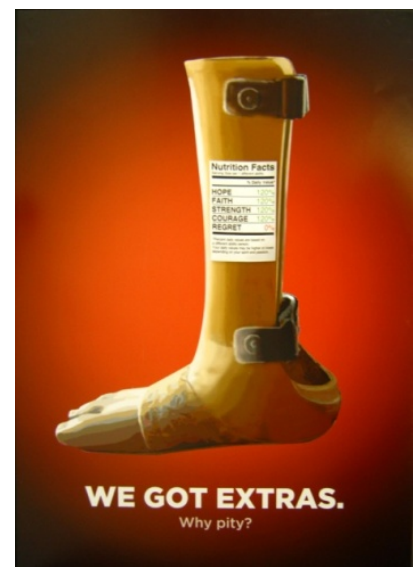

Gambar 11 Poster berjudul We Got Extras karya Angel Stephanie

Poster berjudul Dream Works karya Dian Nadzmi sebagai representamen ditampilkan figur difabel naik kursi roda melayang di udara dengan latar belakang bulan yang bersinar terang berukuran besar dengan latar depan berupa siluet pohon cemara. Visual ini merupakan parodi dari poster film ET dengan figur anak naik sepeda melayang di udara diganti dengan sosok seorang difabel naik kursi roda. Selain itu diperlihatkan headline bertuliskan DreamWorks dengan tampilan menyerupai logo sebuah rumah produksi animasi terkenal. Di bawah headline tercantum subjudul dengan kalimat "The Dream Come True with a Hard Work". Beberapa representamen di sini bekerjasama dan membentuk makna denotatif bahwa setiap orang pasti memiliki impian. Dalam konteks difabilitas representamen ini menimbulkan interpretasi bahwa dengan usaha dan kerja keras, difabel akan dapat meraih yang mereka impikan dan cita-citakan.

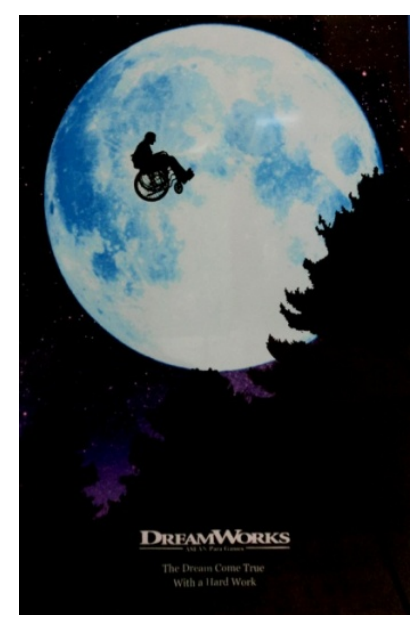

Gambar 12 Poster berjudul Dream Works karya Dian Nadzmi

\section{SIMPULAN}

Dari pameran poster ini dapat disimpulkan bahwa komunikasi dengan empati kepada para difabel adalah yang utama. Dengan adanya empati akan meningkatkan apresiasi masyarakat terhadap para difabel sehingga timbul rasa percaya diri yang lebih tinggi pada diri mereka yang selanjutnya dapat mengantarkan mereka kepada prestasi yang lebih baik lagi. 
Karya ini menyampaikan pesan yang mengobarkan semangat bagi para difabel untuk mandiri, penghargaan bagi mereka, menempatkan posisi para difabel sejajar dengan masyarakat non-difabel. Animo masyarakat untuk mengunjungi pameran ini cukup tinggi dan merespons kegiatan ini dengan positif, terlihat dengan adanya kunjungan dari beberapa yayasan penyandang cacat dan masyarakat di kota Solo mendapat perhatian dari media massa setempat disertai dengan liputan media lokal yang memberitakan kegiatan ini kepada masyarakat, yaitu Solo Pos dan Suara Merdeka. Respons yang positif disampaikan oleh Yayasan Talenta bahwa kegiatan seperti ini perlu sering dilakukan agar masyarakat dapat lebih memahami situasi dan kondisi para difabel dan sebaliknya para difabel pun memiliki semangat untuk dapat lebih mandiri dan berprestasi lebih baik lagi.

\section{DAFTAR PUSTAKA}

Nugroho, S. (2010). Meretas Siklus Kecacatan: Realitas yang terabaikan. Yogyakarta.

Schramm, W. (1954). The process and effects of communication. Urbana: University of Illinois Press.

Smith, D. (2010). Design for content management. Diakses pada 15 Juli 2010, dari: http://www.designartcraft.com/design/folio/design_content_mgt.pdf 